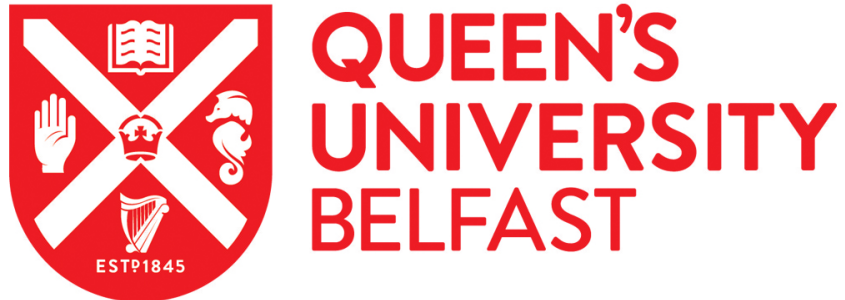

\section{Spatial and temporal influences of in-stream factors on the chemistry and epilithic biomasses of upland stream metal deposits}

Macintosh, K. A., \& Griffiths, D. (2014). Spatial and temporal influences of in-stream factors on the chemistry and epilithic biomasses of upland stream metal deposits. Aquatic Sciences, 76(3), 331-338.

https://doi.org/10.1007/s00027-014-0338-7

\section{Published in:}

Aquatic Sciences

\section{Document Version:}

Peer reviewed version

Queen's University Belfast - Research Portal:

Link to publication record in Queen's University Belfast Research Portal

\section{Publisher rights}

Copyright Springer Basel 2014.

The final publication is available at Springer via http://dx.doi.org/10.1007/s00027-014-0338-7.

\section{General rights}

Copyright for the publications made accessible via the Queen's University Belfast Research Portal is retained by the author(s) and / or other copyright owners and it is a condition of accessing these publications that users recognise and abide by the legal requirements associated with these rights.

Take down policy

The Research Portal is Queen's institutional repository that provides access to Queen's research output. Every effort has been made to ensure that content in the Research Portal does not infringe any person's rights, or applicable UK laws. If you discover content in the Research Portal that you believe breaches copyright or violates any law, please contact openaccess@qub.ac.uk. 
Running Head: INFLUENCES OF IN-STREAM FACTORS ON METAL DEPOSITS

1 Spatial and temporal influences of in-stream factors on the chemistry and epilithic biomasses

2 of upland stream metal deposits

3

4 Katrina Ann Macintosh a, * David Griffiths a

5 a School of Environmental Sciences, University of Ulster, Coleraine, U.K. BT52 1SA

6

$7 \quad$ * Corresponding author:

$8 \quad$ E-mail address: ka.macintosh@ulster.ac.uk

9 Tel.: +44 (0) 2870124426

10 Fax: +44 (0) 2870124911 
Running Head: INFLUENCES OF IN-STREAM FACTORS ON METAL DEPOSITS

\section{Abstract}

12

The density and composition of stream bed metal deposits are affected by physical, chemical and

14 biological processes. In this paper we investigate the importance of these processes and their relation

15 to algal and non-photosynthetic detrital (NPD) biomass in a set of upland streams in Northern Ireland.

16 Deposit density and $\mathrm{Fe}, \mathrm{Mn}, \mathrm{Al}$ and $\mathrm{P}$ concentrations varied with stream $\mathrm{pH}$ across sites but not

17 seasonally. No effects of stream bed erosion or photoreduction were detected on deposit densities.

18 Seasonal variation in stream water metal concentrations was correlated with rainfall. NPD biomass

19 was a significant predictor of both spatial and seasonal variation in deposit concentrations. There were strong, non-linear, relations between NPD biomass and deposit metal concentrations, with $\mathrm{Fe}$ and $\mathrm{Mn}$ becoming relatively more important and algal biomass declining above threshold deposit/NPD densities. The results suggest that NPD biomass influences deposit density and reduces the biomass of photosynthetic autotrophs above a threshold deposit density.

\section{Keywords}

Iron deposits · Epilithic algae · pH · Dissolved oxygen · Rainfall · Photoreduction 


\section{Introduction}

Deposits of iron oxide in surface waters have been documented globally (Niyogi et al. 1999; Prange 2007; Neal et al. 2008) and are frequently reported in post-industrial landscapes impacted by acid mine drainage (Younger 2001; Kimball et al. 2002; Mayes et al. 2008). Stream metal deposits are also found in non-industrial, often upland, catchments with limited anthropogenic activity. In impacted areas, metal rich precipitates are ubiquitous and envelop benthic habitats. Smothering by flocculent precipitates reduces light penetration and oxygen circulation at the substrate level within streams (Mayes et al. 2008), which in turn has negative impacts for benthic primary producers and limits nutrient transfer between trophic levels. The deposits have potentially harmful effects for algae, invertebrates and fish (Vuori 1995; Jarvis and Younger 1997).

A variety of physical, chemical and biological factors determine the quantity of metal-rich deposits found in some upland streams through redox processes. An extensive literature documents the mobilisation of soluble ferrous iron (Fe) under acidic, deoxygenated conditions, as found in waterlogged peaty soils, and the precipitation of the ferric form in less acidic, more oxygenated, surface waters (Crerar et al. 1979; McKnight and Feder 1984; Abesser et al. 2006; Prange 2007). pH, oxygen and temperature are highlighted as important environmental factors controlling the speciation of Fe; the influence of $\mathrm{pH}$ on oxidation rate is strongest under circumneutral conditions (Morgan and Lahav 2007). Photoreduction (Madsen et al. 1986; McKnight et al. 1988; McKnight et al. 2001) and the erosion of deposits by stream flow (Abesser et al. 2006) reduce the amount of deposit material diurnally and seasonally. Manganese (Mn) behaves similarly to Fe (Rowland et al. 2012), although it precipitates at a higher oxygen concentration (Stumm and Morgan 1996) and its oxide minerals can scavenge substantial amounts of many metals, including Fe from the environment (Tebo et al. 2004).

Stream bed organic matter can be divided into phototrophic (algal) and non-photosynthetic detrital (NPD) components: NPD potentially consists of bacteria, fungi, extracellular biofilms and detritus of terrestrial or aquatic origin (Ledger and Hildrew 1998; Carr et al. 2005). Bacteria are the most common agents of Fe deposition, although algae and fungi can precipitate metals under some circumstances (Ghiorse 1984; Trouwborst et al. 2007). Metal-oxidising bacteria are significant biogenic agents (Crerar et al. 1979; Konhauser 1998; Tebo et al. 2004; Emerson et al. 2010) and cause/enhance the deposition of metals in streams as (hydr)oxides. For example, Leptothrix and Gallionella, common bacterial genera inhabiting Fe- and Mn-rich freshwater environments (Johnson et al. 2012), occur at circumneutral $\mathrm{pH}$ and are characterised by the extensive production of oxide encrusted sheaths and stalks (Ghiorse 1984; Sheldon and Wellnitz 1998). In addition, aluminium (Al), Fe and Mn compounds precipitate/complex with phosphorus $(P)$, with potential nutrient supply effects for biofilm organisms.

Catchment (soil type and geology) and in-stream ( $\mathrm{pH}$ and dissolved oxygen (DO)) variables influence stream water metal concentrations in upland streams in Northern Ireland (Macintosh and Griffiths 2013). In this study, we investigate the factors that affect deposit concentrations and algal and NPD biomasses both spatially and temporally. The purpose of this process-level study was to investigate: 
(1) If stream water chemistry, and in particular $\mathrm{pH}$ and $\mathrm{DO}$, affects metal deposit concentrations by altering metal solubility (Hem 1972; McKnight and Bencala 1990; Prange 2007). Deposit concentrations should increase with stream $\mathrm{pH}$ and $\mathrm{DO}$.

(2) Whether stream bed erosion and/or photoreduction affect deposit density. Catchment hydrology and the rate of flushing are known to affect stream water metal loading and deposit metal concentrations (Abesser et al. 2006). If so, deposit density should vary seasonally, being negatively correlated with rainfall and day length.

(3) The relative importance of epilithic algae and NPD in determining deposit composition and whether biotic or abiotic processes affect stream bed deposit concentrations. Photo- and litho-trophic activity may control stream deposit metal concentrations (Konhauser 1998; Emerson et al. 2010). The relative contributions of $\mathrm{pH}$ and deposit organic matter to predicting deposit inorganic matter concentrations should help to identify the roles of chemical and biological processes, respectively. This hypothesis was tested by determining the contributions of in-stream factors $(\mathrm{pH}, \mathrm{DO}$, algal and NPD biomasses) and rainfall to predicting deposit density and composition.

\section{Materials and methods}

\section{Study area}

Macintosh and Griffiths (2013) have described the study sites adopted in a survey of 52 sites located in two geologically distinct upland areas of Northern Ireland. Sites lack anthropogenic interference and are not impacted by mining activities. The current paper uses data collected in April 2007 from 32 of these sites, located in the Sperrin Mountains, and from eight of these sites in two adjacent catchments, sampled approximately monthly on 12 occasions between November 2007 and September 2008. Sites were selected across a range of deposit metal concentrations. All streams were located on open moorland, had well-oxygenated water and stony substrata: no aquatic macrophytes were observed. Streamflow tended to be 'flashy', with rapid fluctuations between high and low flow discharge. Medians and ranges of physical, chemical and biotic variables across sites are summarised in Table 1: with the exception of oxygen saturation levels the variables vary by 1-3 orders of magnitude across sites. The benthic chlorophyll a and phosphorus concentrations indicate that these streams are oligotrophic (Dodds et al. 1998).

\section{Sampling and laboratory analysis}

Water chemistry procedures for Fe, Mn and Al are detailed in Macintosh and Griffiths (2013). Stream water total phosphorus $(\mathrm{P})$ concentrations were determined by spectrometry using the molybdateantimony method (Murphy and Riley 1958, 1962). Stream water was analysed, in situ, for DO, temperature, conductivity and $\mathrm{pH}$. A HACH HQ 10 portable meter with LDO probe was used to measure $\mathrm{DO}\left(\%\right.$ saturation) and temperature $\left({ }^{\circ} \mathrm{C}\right)$, while a $\mathrm{HACH}$ sensION ${ }^{\mathrm{TM}} 156$ portable meter was 
used to measure conductivity $\left(\mu \mathrm{S} \mathrm{cm}^{-1}\right)$ and $\mathrm{pH}$. Probes were calibrated prior to sampling in accordance with $\mathrm{HACH}$ operation manuals.

On each sampling occasion, seven stream bed stones were randomly removed from each site and bagged individually for analysis of deposit composition and epilithic chlorophyll a concentration. Deposit material on the upper stone surface was removed by spatula, brush and rinsing with Millipore Milli-Q grade water. Depending on density, the material from two to three stones was amalgamated and dried at $105^{\circ} \mathrm{C}$ until there was no further weight loss. Inorganic matter (IM) was determined after ashing deposit samples for 1 hour in a muffle furnace at $550^{\circ} \mathrm{C}$, and organic matter content (OM) estimated as the loss-on-ignition (Lamberti and Resh 1985). Deposit density was calculated as the dry mass of material per unit surface area, the latter determined by covering the exposed stone surface with aluminium foil which was then weighed. Surface area of the stones collected varied five-fold, from $49-259 \mathrm{~cm}^{2}$, but surface area did not affect deposit density estimates (two-way ANOVA with site and area as variables; $F_{1,196}=1.22, P>0.2$ ): similar results were obtained for each metal. IM was strongly correlated with total deposit density $(r=0.99, n=32, P<0.001)$ : it comprised on average $68 \%$ of deposit (range $47-92 \%$ ). After sequential digestion with concentrated hydrofluoric, nitric, and perchloric acids, deposit chemistry was measured by spectrometry as described for water chemistry by Macintosh and Griffiths (2013).

Epilithic algal chlorophyll a concentrations on four stones were determined following the procedure of Marker et al. (1980), after cold extraction in the dark at $4^{\circ} \mathrm{C}$. Optimum stone sampling effort for chlorophyll a concentration was determined by bootstrapping, using a Mersenne-Twister random number generator, to randomly resample 1000 observations with replacement, from an original sample of 10 (Quinn and Keogh 2002). Published data on ash free dry weight (AFDW) and chlorophyll a concentrations (Chla) were compiled and the autotrophic index (AFDW/Chla), an indicator of the relative importance of phototrophic and lithotrophic biomass components, was calculated. Indices less than $\mathbf{2 0 0}$ were taken as indicative of sites where photosynthesis dominated primary production (Rice et al. 2012), higher values indicating predominantly lithotrophic production. Using the equation derived from published data (Clark et al. 1979; Weitzel et al. 1979; Biggs 1996; Carpenter 2003) for non-Fe deposit sites with an autotrophic index $<200(\log A F D W=2.016+$ $1.043 \pm 0.026 \log$ Chla, $r^{2}=0.98, n=37$ ), we estimated the AFDW attributable to photosynthetic organisms (algal biomass) from measured deposit chlorophyll a concentrations. The difference between algal biomass and the corresponding OM values was used as an estimate of "nonphotosynthetic detrital' (NPD) biomass. NPD biomass includes extracellular and allochthonous organic matter, dead algae, bacteria and fungi (Ledger and Hildrew 1998; Carr et al. 2005).

Dissolved organic carbon (DOC, data supplied from the Geological Survey of Northern Ireland Tellus Project) is an important energy/nutrient source for lithotrophs (Bott et al. 1984; Tranvik 1988), and should be correlated with the NPD biomass estimates: it was, but not with algal biomass $(r=$ $0.42, n=30, P<0.05 ; r=-0.11, n=30, P>0.5$, respectively). The Tellus Project data were collected at a different spatial scale and on different dates from our samples, so as a check on comparability we calculated correlations between variables measured in common (conductivity, $\mathrm{pH}, \mathrm{Fe}, \mathrm{Mn}, \mathrm{Al}$ ): the 
correlation for Al was not significant $(r=0.20)$ but those for the other variables were $(r=0.75-0.86, n$ $=30, P<0.001)$.

If photoreduction has a significant seasonal effect on deposit concentration, a negative correlation between day length and concentration would be expected. Day length for the sample dates was estimated for the mean latitude and longitude of the sites (using http://aa.usno.navy.mil/data/docs/RS OneYear.html), while mean values across sites were used for all deposit variables. The low angle of the sun in the winter results in greater reflection and less light penetration, and consequently day length overestimates photic effects.

To assess the role of flushing from the catchment daily rainfall data for October 2007 to October 2008 was obtained from the Meteorological Office weather station at Banagher, Caugh Hill, on the edge of the Sperrin Mountains, the closest station (10-12 km north) to the eight seasonal study sites.

\section{Statistical analysis}

The effect of rainfall on deposit concentrations was determined by calculating the cumulative rainfall in the $3,7,14$ and 28 day periods prior to sampling. To summarise rainfall effects, the numbers of significant correlations were expressed as fractions of possible correlations.

All variables, except temperature, $\mathrm{DO}$ and $\mathrm{pH}$, were $\log _{10}$ transformed to normalise the data. In the majority of tests, a $5 \%$ significance level was used; but significance levels between rainfall and metal concentrations in stream water were increased to $10 \%$ to reduce the risk of type 2 error with the low-resolution rainfall data. To test for non-linearity, the fits of piecewise (Toms and Lesperance 2003) and linear regression models were compared using $\mathrm{AIC}_{\mathrm{c}}$. Non-linear lines were fitted to the data using locally weighted scatterplot smoothers (lowess).

\section{Results and Discussion}

\section{Effect of stream water chemistry}

Stream water in the Sperrin Mountains was usually saturated with oxygen (Table 1: seasonal data, median DO 105\%, range $94-117 \%$ ), whereas $\mathrm{pH}$ was more variable (median 6.7, range 4.6 - 8.7) (mean coefficients of variation \pm s.e. for $\mathrm{DO}$ and $\mathrm{pH} 0.057 \pm 0.004 ; 0.115 \pm 0.008, t=6.19, P<0.001$ ) and hence $\mathrm{pH}$ would be expected to be more important in determining metal deposition variation. Across all sites, deposit density and total $\mathrm{Fe}, \mathrm{Mn}, \mathrm{Al}$ and $\mathrm{P}$ deposit concentrations were negatively correlated with $\mathrm{pH}$, but only Fe showed a correlation with $\mathrm{DO}(\mathrm{pH} r=-0.44--0.53, P<0.05$; DO Fe $r=$ $-0.41, n=25, P<0.05)$.

There were consistent temporal trends in stream water chemistry (results not shown) and in deposit concentrations across sites (Kendall coefficient of concordance: deposit $\chi^{2}=56.7, P<0.001$; Fed $\chi^{2}=62.2, P<0.001 ; \mathrm{Mnd}_{\mathrm{d}} \chi^{2}=55.7, P<0.001 ; \mathrm{Al}_{\mathrm{d}} \chi^{2}=32.7, P<0.001 ; \mathrm{Pd} \chi^{2}=37.3, P<0.001$ ), suggesting that this variation is driven by seasonal factors. 
$\mathrm{pH}$ and $\mathrm{DO}$ are recognised in the literature as major determinants of metal solubility (Hem 1972; McKnight and Bencala 1990; Prange 2007) and hence potentially important predictors of chemical metal precipitation within stream systems. The lower variability in DO may relate to the turbulent dynamics of the upland stream sites, which are generally fast flowing and subsequently well oxygenated. However, the negative correlations between the deposits and $\mathrm{pH}$ and $\mathrm{DO}$ are contrary to expectation if deposition is controlled by chemical processes and stream water concentrations.

Erosion and photoreduction

There was little evidence of a stream bed erosion effect; only three of 32 possible correlations ( 8 sites $x 4$ rainfall periods) between rainfall and deposit density were significant and only two were negative. Mean deposit Fe, OM and NPD biomass concentrations increased with day length, contrary to expectation if there was a strong photoreduction effect $(r=0.78,0.69,0.71, n=9, P<0.05$, respectively): there was no temperature effect on any of the deposit variable concentrations.

Failure to detect erosion and photoreduction effects on stream bed deposits is probably more a reflection of sampling resolution than the absence of such effects. For example, on several occasions the majority of tiles secured to the stream bed to measure deposit accrual rates were lost, indicative of strong erosional episodes. Nevertheless, the short-term ( $<7$ day) correlations between rainfall and deposit concentration are positive, inconsistent with an erosion effect. Fe and DOC surface water concentrations are positively correlated (Molot and Dillon 2003; Neal et al. 2008; Macintosh and Griffiths 2013), because both are derived largely from the catchment (Vuori 1995). However, $\mathrm{Fe}^{3+}$ forms complexes with dissolved OM, which increases the likelihood of photoreduction. Photoreduction occurs with a diurnal cycle (McKnight et al. 1988; McKnight et al. 2001), so the positive seasonal correlation with day length which we report must be due to some other process.

\section{Catchment flushing}

Over the year, the greatest number of significant correlations was between stream water metal $(\mathrm{Fe}$, $\mathrm{Mn}, \mathrm{Al}$ ) concentrations and total rainfall in the previous 8-14 days (8 sites $\times 3$ variables $\times 4$ rainfall periods $=96$ possible correlations: $1-3$ days, $6 / 96$ significant at $P<0.10 ; 4-7$ days, $5 / 96 ; 8-14$ days, $17 / 96 ; 15-28$ days, 1/96). It should be noted that the overall number of correlations is similar to that expected by chance: higher resolution data are necessary to confirm a rainfall effect. All significant correlations for rainfall periods up to 7 days were positive, consistent with a short-term flushing effect from the soil, but for longer periods all correlations were negative. All Fe correlations (8 sites) were negative, but positive and negative correlations occurred for Mn (6/14 positive) and Al (5/7 positive).

Precipitation and translocation of water through various hydrological pathways is responsible for nutrient and metal transport into lotic systems (Carlyle and Hill 2001; Abesser et al. 2006). Hence, low rainfall can result in high soil metal concentrations, while persistent heavy rainfall following a dry period can flush metals from soils into streams, but with concentrations declining as material is removed. Abesser et al. (2006) identified soilwater and groundwater sources for Fe and Mn in three 
upland catchments. They concluded that metals were flushed from the soil during storm events and that the lower concentration groundwater source became more important as the soil reservoir was depleted. Fe, $\mathrm{Mn}$ and $\mathrm{Al}$ water concentrations were shown to respond positively and rapidly to increases in streamflow. Such relationships are detectable with in-situ monitoring equipment for the collection of site-specific, hydrometric and water chemistry data: high-resolution data were not collected as part of this study. However, the short-term ( $<7$ days) positive and the longer-term $(>7$ days) negative correlations observed in our data could be generated by a similar relationship, although the stream water metal responses to rainfall appear to be much slower than those observed by Abesser et al. (2006).

\section{Deposit composition}

Deposit IM concentrations were predicted by deposit OM concentrations but not by pH or DO (Table 2a) and NPD biomass was a stronger predictor than algal biomass (Table 2b). Deposits tended to be dominated by either algal or NPD biomass (Fig. 1): none of the in-stream variables were distributed bimodally. Algal biomass across sites was not correlated with any of the other deposit variables, which were strongly correlated with each other $(r=0.56-0.90$, median $0.76, n=15)$ and with the first principal component (PCA) axis (Table 3): Al showed an intermediate association with the PCA axes. The first two factors accounted for $85 \%$ of the variation in deposit composition. There were marked seasonal changes in algal biomass but much less change in NPD biomass (Fig. 2).

Across the 32 sites, NPD biomass had stronger effects on deposit metal concentrations than algal biomass or stream water concentrations (Table 4a). Similarly, across sample dates, NPD biomass was a significant predictor for all determinants, whereas $\mathrm{pH}, 7$ day rainfall and algal biomass were only occasionally significant (Table 4b).

OM content increased linearly with overall deposit density, which is to be expected since it comprised an average of 32\% (range 8-53\%) of the deposit. However, metal and P concentrations across the eight intensively studied sites exhibited non-linear relations with NPD biomass (Table 5 , Fig. 3), OM and deposit density: concentrations showed small (Fe, P) or no increases ( $\mathrm{Mn}, \mathrm{Al}$ ) up to deposit densities of 4-8 $\mathrm{mg} \mathrm{cm}^{-2}$ before increasing more rapidly. Above the breakpoint the slope for $\mathrm{Fe}, \mathrm{Mn}$ and $\mathrm{P}$ was greater than 1.0, indicating an increasing proportion of these substances in the deposit, whereas the proportion of Al declined.

Algal biomass showed weak but significant, dome-shaped, relationships with NPD biomass, $\mathrm{OM}$ and deposit density (quadratic $r=0.29, n=80, P<0.05 ; r=0.33, n=80, P=0.01 ; r=0.29, n=80$, $P<0.05$, respectively) i.e. algal biomass was lower in the most $\mathrm{OM}$ rich and deposit dense sites.

$\mathrm{DO}$ and $\mathrm{pH}$ were not significant predictors of variation in deposit metal concentrations once deposit biomass was included in the analyses (Tables $2 \& 4$ ), with NPD biomass having the statistically dominant effect. Both Fe and Mn can be precipitated by purely chemical processes, but Fe and Mn-oxidising bacteria are also frequently involved (Ehrlich and Newman 2009). The majority of Mn oxides are biogenic in origin (Tebo et al. 2004), while Emerson et al. (2010) note that bacteria are responsible for about half the Fe oxidised in freshwaters. Bacterial growth rates surpass those of 
epilithic algae and bacteria are considered superior competitors for inorganic nutrients and space (Rier and Stevenson 2002). The strong relationships between NPD biomass and Fe and Mn concentrations in the stream bed deposits, but not with stream water concentrations, support a biogenic effect. While phototrophic activity can drive Fe deposition under some circumstances (Trouwborst et al. 2007), it seems unlikely to do so in the oligotrophic streams studied.

The bimodal distribution of epilithic algal biomass as a percentage of $\mathrm{OM}$ and the decline in algal biomass at high NPD biomass are both consistent with increasing metal deposition and a competitive interaction with lithotrophs. NPD biomass potentially includes extracellular and allochthonous organic matter (Ledger and Hildrew 1998; Carr et al. 2005), dead algae, bacteria, fungi and bacterial sheaths, in addition to live bacteria and fungi. There was little visible coarse particulate organic matter (CPOM) or fungal material in the samples (Macintosh K.A. unpublished data), but empty Leptothrix ochracea sheaths and the stalks of Gallionella ferruginea were observed under a microscope. Due to the scarcity of CPOM and fungi, we tentatively conclude that bacteria and/or their sheaths could be responsible for metal deposition. Elevated concentrations of Fe and $\mathrm{Mn}$ in streams promote the transition from photosynthetic production to lithotrophy, through the suppression of algal activity and/or increased bacterial populations (Sheldon and Skelly 1990; Rier and Stevenson 2002).

\section{Conclusions}

In this paper we investigated the spatial and temporal influences exerted by in-stream factors on the chemistry and epilithic biomasses of upland stream metal deposits. Deposit density and concentrations of $\mathrm{Fe}, \mathrm{Mn}, \mathrm{Al}$ and $\mathrm{P}$ varied with NPD biomass. Seasonal variation in stream water metal concentrations was correlated with rainfall; however, no effects of stream bed erosion or photoreduction were detected on deposit densities. Strong, non-linear relations exist between NPD biomass and deposit metal concentrations, with Fe and Mn becoming relatively more important and algal biomass declining above threshold deposit/NPD densities.

Our results, while only correlative, suggest the potential importance of microbial lithotrophic activity in determining seasonal patterns in deposit chemistry in naturally occurring, iron-impacted stream systems. A potentially important relationship exists between non-photosynthetic detrital biomass and the deposition of iron-oxides. This finding supports the growing body of literature that proposes a link between organic carbon and iron deposition (Weiss et al. 2003; Roden et al. 2012). Further investigation into the specific microbial mat ecology of such naturally occurring iron deposits is necessary to quantify the importance of bacterial oxidation of Fe and Mn.

\section{Acknowledgements}

Katrina Macintosh was funded by a Department for Employment and Learning studentship at the University of Ulster. We thank Joerg Arnscheidt, Phil Jordan, Brian Rippey and two anonymous referees for helpful comments on earlier drafts of the manuscript. We gratefully acknowledge the Geological Survey of Northern Ireland for providing access to the Tellus Project data set. The Tellus Project was financed by the Department of Enterprise, Trade and Investment and by the Building 
Running Head: INFLUENCES OF IN-STREAM FACTORS ON METAL DEPOSITS

305 Sustainable Development Programme (Department of Agriculture and Rural Development) and is 306 reproduced with the permission of the Director of the Geological Survey of Northern Ireland. ( $)$ Crown

307 Copyright (2012). Thanks also to the Meteorological Office in Exeter for providing daily rainfall data for 308 Banagher. 


\section{References}

Abesser C, Robinson R, Soulsby C (2006) Iron and manganese cycling in the storm runoff of a Scottish upland catchment. J Hydrol 326:59-78. doi:10.1016/j.jhydrol.2005.10.034

Biggs BJF (1996) Patterns in benthic algae of streams. In: Algal ecology: freshwater benthic ecosystems. Academic Press, San Diego, pp 31-56

Bott TL, Kaplan LA, Kuserk FT (1984) Benthic bacterial biomass supported by streamwater dissolved organic matter. Microb Ecol 10:335-344

Carlyle GC, Hill AR (2001) Groundwater phosphate dynamics in a river riparian zone: effects of hydrologic flowpaths, lithology and redox chemistry. J Hydrol 247:151-168

Carpenter KD (2003) Water-quality and algal conditions in the Clackamas River Basin, Oregon, and their relations to land and water management. U.S. Geological Survey Water-Resources Investigations Report 02-4189.

Carr GM, Morin A, Chambers PA (2005) Bacteria and algae in stream periphyton along a nutrient gradient. Freshwater Biol 50:1337-1350. doi:10.1111/j.1365-2427.2005.01401.x

Clark JR, Dickson KL, Cairns J (1979) Estimating aufwuchs biomass. In: Weitzel RL (ed) Methods and measurements of periphyton communities: a review. American Society for Testing and Materials, Philadelphia, pp 116-141

Crerar DA, Knox GW, Means JL (1979) Biogeochemistry of bog iron in the New Jersey Pine Barrens. Chem Geol 24:111-135

Dodds WK, Jones JR, Welch EB (1998) Suggested classification of stream trophic state: distributions of temperate stream types by chlorophyll, total nitrogen, and phosphorus. Water Res 32:1455-1462

Ehrlich HL, Newman DK (2009) Geomicrobiology. 5th edn. CRC Press, Boca Raton

Emerson D, Fleming EJ, McBeth JM (2010) Iron-oxidizing bacteria: an environmental and genomic perspective. Annu Rev Microbiol 64:561-583. doi:10.1146/annurev.micro.112408.134208

Ghiorse WC (1984) Biology of iron- and manganese-depositing bacteria. Annu Rev Microbiol 38:515550

Hem JD (1972) Chemical factors that influence the availability of iron and manganese in aqueous systems. Geological Society of America Bulletin 83:443-450

Jarvis AP, Younger PL (1997) Dominating chemical factors in mine water induced impoverishment of the invertebrate fauna of two streams in the Durham Coalfield, UK. Chemistry and Ecology $13: 249-270$

Johnson KW, Carmichael MJ, McDonald W, Rose N, Pitchford J, Windelspecht M, Karatan E, Bräuer SL (2012) Increased abundance of Gallionella spp., Leptothrix spp. and total bacteria in response to enhanced $\mathrm{Mn}$ and Fe concentrations in a disturbed Southern Appalachian high elevation wetland. Geomicrob J 29:124-138. doi:10.1080/01490451.2011.558557

Kimball BA, Runkel RL, Walton-Day K, Bencala KE (2002) Assessment of metal loads in watersheds affected by acid mine drainage using tracer injection and synoptic sampling: Cement Creek, Colorado, USA. Appl Geochem 17:1183-1207

Konhauser KO (1998) Diversity of bacterial iron mineralization. Earth-Sci Rev 43:91-121 
Lamberti GA, Resh VH (1985) Comparability of introducing tiles and natural substrates for sampling lotic bacteria, algae and macroinvertebrates. Freshwater Biol 15:21-30

Ledger ME, Hildrew AG (1998) Temporal and spatial variation in the epilithic biofilm of an acid stream. Freshwater Biol 40:655-670

Macintosh KA, Griffiths D (2013) Geological and soil effects on iron, manganese and aluminium concentrations in upland streams. Environ Earth Sci 70:3023-3030. doi:10.1007/s12665-0132363-6

Madsen EL, Morgan MD, Good RE (1986) Simultaneous photoreduction and microbial oxidation of iron in a stream in the New Jersey Pinelands. Limnol Oceanogr 31:832-838

Marker AFH, Crowther CA, Gunn RJM (1980) Methanol and acetone as solvents for estimating chlorophyll $a$ and phaeopigments by spectrophotometry. Archiv für Hydrobiologie Beiheft Ergebnisse der Limnologie 14:52-69

Mayes WM, Gozzard E, Potter HAB, Jarvis AP (2008) Quantifying the importance of diffuse minewater pollution in a historically heavily coal mined catchment. Environ Pollut 151 165175. doi:10.1016/j.envpol.2007.02.008

McKnight D, Kimball B, Bencala K (1988) Iron photoreduction and oxidation in an acidic mountain stream. Science 240:637-640

McKnight DM, Bencala KE (1990) The chemistry of iron, aluminium, and dissolved organic material in three acidic, metal-enriched mountain streams, as controlled by watershed and in-stream processes. Water Resour Res 26:3087-3100. doi:10.1029/WR026i012p03087

McKnight DM, Feder GL (1984) The ecological effect of acid conditions and precipitation of hydrous metal oxides in a Rocky Mountain stream. Hydrobiologia 119:129-138

McKnight DM, Kimball BA, Runkel RL (2001) pH dependence of iron photoreduction in a rocky mountain stream affected by acid mine drainage. Hydrol Process 15:1979-1992. doi:10.1002/hyp.251

Molot LA, Dillon PJ (2003) Variation in iron, aluminum and dissolved organic carbon mass transfer coefficients in lakes. Water Res 37 1759-1768

Morgan B, Lahav O (2007) The effect of $\mathrm{pH}$ on the kinetics of spontaneous $\mathrm{Fe}(\mathrm{II})$ oxidation by $\mathrm{O}_{2}$ in aqueous solution - basic principles and a simple heuristic description. Chemosphere 68 2080-2084. doi:10.1016/j.chemosphere.2007.02.015

Murphy J, Riley JP (1958) A single-solution method for the determination of soluble phosphorus in sea water. J Mar Biol Soc UK 37:9-14

Murphy J, Riley JP (1962) A modified single solution method for the determination of phosphate in natural waters. Anal Chim Acta 27:31-36

Neal C, Lofts S, Evans CD, Reynolds B, Tipping E, Neal M (2008) Increasing iron concentrations in UK upland waters. Aquat Geochem 14:263-288. doi:10.1007/s10498-008-9036-1

Niyogi DK, McKnight DM, Lewis WM (1999) Influences of water and substrate quality for periphyton in a montane stream affected by acid mine drainage. Limnol Oceanogr 44:804-809

Prange $H$ (2007) Ochre pollution as an ecological problem in the aquatic environment: solution attempts from Denmark. Edmund Siemers-Stiftung, Hamburg 
Quinn GP, Keogh MJ (2002) Experimental design and data analysis for biologists. Cambridge University Press, Cambridge

Rice EW, Baird RB, Eaton AE, Clesceri LS (2012) Standard methods for the examination of water and wastewater. 22nd edn. American Public Health Association, Washington, D.C.

Rier ST, Stevenson RJ (2002) Effects of light, dissolved organic carbon, and inorganic nutrients on the relationship between algae and heterotrophic bacteria in stream periphyton. Hydrobiologia 489:179-184

Roden EE, McBeth JM, Blöthe M, Percak-Dennett EM, Fleming EJ, Holyoke RR, Luther GW, Emerson D, Schieber J (2012) The microbial ferrous wheel in a neutral pH groundwater seep. Frontiers in Microbiology 3:172. doi:10.3389/fmicb.2012.00172

Rowland AP, Neal C, Reynolds B, Neal M, Lawlor AJ, Sleep D (2012) Manganese in the upper Severn mid-Wales. J Environ Monit 14:155-164. doi:10.1039/C1EM10651A

Sheldon SP, Skelly DK (1990) Differential colonization and growth of algae and ferromanganesedepositing bacteria in a mountain stream. Journal of Freshwater Ecology 5:475-485

Sheldon SP, Wellnitz TA (1998) Do bacteria mediate algal colonization in iron-enriched streams? Oikos 83:85-92

Stumm W, Morgan JJ (1996) Aquatic chemistry. 3rd edn. J Wiley \& Sons, New York

Tebo BM, Bargar JR, Clement BG, Dick GJ, Murray KJ, Parker D, Verity R, Webb SM (2004) Biogenic manganese oxides: properties and mechanisms of formation. Annu Rev Earth PI Sc 32:287328. doi:10.1146/annurev.earth.32.101802.120213

Toms JD, Lesperance ML (2003) Piecewise regression: a tool for identifying ecological thresholds. Ecology 84:2034-2041

Tranvik LJ (1988) Availability of dissolved organic carbon for planktonic bacteria in oligotrophic lakes of differing humic content. Microb Ecol 16:311-322

Trouwborst RE, Johnston A, Koch G, Luther GW, Pierson BK (2007) Biogeochemistry of Fe(II) oxidation in a photosynthetic microbial mat: Implications for Precambrian Fe(II) oxidation. Geochimica et Cosmochimica Acta 71:4629-4643. doi:10.1016/j.gca.2007.07.018

Vuori K-M (1995) Direct and indirect effects of iron on river ecosystems. Ann Zool Fenn 32:317-329

Weiss JV, Emerson D, Backer SM, Megonigal JP (2003) Enumeration of Fe(II)-oxidizing and Fe(III)reducing bacteria in the root zone of wetland plants: Implications for a rhizosphere iron cycle. Biogeochemistry 64:77-96

Weitzel RL, Sanocki SL, Holecek H (1979) Sample replication of periphyton collected from artificial substrates. In: Weitzel RL (ed) Methods and measurements of periphyton communities. American Society for Testing and Materials, Philadelphia, pp 90-115 Younger PL (2001) Mine water pollution in Scotland: nature, extent and preventative strategies. Sci Total Environ 265 309-326 
Running Head: INFLUENCES OF IN-STREAM FACTORS ON METAL DEPOSITS

427 Table 1 Medians and ranges of physical, chemical and biotic variables across the 32 study sites.

428

\begin{tabular}{lrr} 
Variable & Median & Range \\
\hline Water & & \\
$\mathrm{pH}$ & 7.5 & $6.6-7.8$ \\
$\mathrm{DO}(\%)$ & 100.8 & $92.2-111.3$ \\
$\mathrm{Fe}\left(\mathrm{mg} \mathrm{L}^{-1}\right)$ & 1.37 & $0.01-6.28$ \\
$\mathrm{Mn}\left(\mathrm{mg} \mathrm{L}^{-1}\right)$ & 0.39 & $0.02-1.59$ \\
$\mathrm{Al}\left(\mathrm{mg} \mathrm{L}^{-1}\right)$ & 0.08 & $0.02-0.94$ \\
$\mathrm{P}\left(\mathrm{mg} \mathrm{L}^{-1}\right)$ & 0.01 & $0.005-0.039$
\end{tabular}

Deposit

$\begin{array}{lrr}\text { Density }\left(\mathrm{g} \mathrm{m}^{-2}\right) & 65.0 & 5.7-347.0 \\ \mathrm{Fe}\left(\mathrm{g} \mathrm{m}^{-2}\right) & 5.7 & 0.2-52.5 \\ \mathrm{Mn}\left(\mathrm{g} \mathrm{m}^{-2}\right) & 0.5 & 0.03-14.5 \\ \mathrm{Al}\left(\mathrm{g} \mathrm{m}^{-2}\right) & 1.0 & 0.2-8.9 \\ \mathrm{P}\left(\mathrm{g} \mathrm{m}^{-2}\right) & 0.1 & 0.01-0.8 \\ \mathrm{IOM}\left(\mathrm{g} \mathrm{m}^{-2}\right) & 44.8 & 4.1-280.3 \\ \mathrm{OM}\left(\mathrm{g} \mathrm{m}^{-2}\right) & 16.0 & 1.6-83.2 \\ \text { Algal biomass }\left(\mathrm{g} \mathrm{m}^{-2}\right) & 2.2 & 0.1-45.2 \\ \text { NPD biomass }\left(\mathrm{g} \mathrm{m}^{-2}\right) & 10.2 & 1.0-82.6 \\ \text { Autotrophic index } & 1319 & 42-20518\end{array}$

429 
430 Table 2 Standardised multiple linear regression coefficients, showing inorganic matter concentration

431 in the deposit varies (a) with deposit organic matter content $\left(R^{2}=0.76\right)$ and (b) with NPD biomass $\left(R^{2}\right.$ $432=0.73)$.

433

434

(a)

\begin{tabular}{lll}
\hline Variable & Std Coeff & $t$ \\
\hline $\mathrm{pH}$ & $0.011 \pm 0.040$ & 0.29 \\
$\mathrm{DO}$ & $-0.009 \pm 0.037$ & 0.24 \\
Organic matter & $0.865 \pm 0.102$ & $8.51^{\star \star \star}$
\end{tabular}

435

436

(b)

\begin{tabular}{lll}
\hline Variable & Std Coeff & $t$ \\
\hline Algal biomass & $0.129 \pm 0.067$ & 1.92 \\
NPD biomass & $0.750 \pm 0.098$ & $7.66^{\star \star \star}$
\end{tabular}

$437 \quad P<0.05^{\star}, P<0.01^{\star \star}, P<0.001^{\star \star \star}$

438 
Running Head: INFLUENCES OF IN-STREAM FACTORS ON METAL DEPOSITS

439 Table 3 PCA component loadings on the first two axes for stone deposit (d) variables. Significant 440 loadings $(P<0.05)$ are shown in bold.

441

\begin{tabular}{lrr}
\hline & Factor 1 & Factor 2 \\
\hline Fed & $\mathbf{0 . 9 4 3}$ & 0.128 \\
$\mathrm{Mn}_{d}$ & $\mathbf{0 . 8 4 3}$ & 0.255 \\
$\mathrm{Ald}$ & $\mathbf{0 . 7 4 5}$ & $\mathbf{- 0 . 4 3 7}$ \\
$\mathrm{P}_{\mathrm{d}}$ & $\mathbf{0 . 8 9 8}$ & 0.149 \\
Inorganic matter & $\mathbf{0 . 9 4 1}$ & -0.208 \\
Algal biomass & 0.037 & $-\mathbf{0 . 9 6 4}$ \\
NPD biomass & $\mathbf{0 . 9 0 0}$ & 0.096 \\
\hline \% variance & 66.6 & 18.2 \\
\hline
\end{tabular}

442 
Table 4 Summary of multiple linear regressions, showing standardised coefficients of variables tested

(a)

\begin{tabular}{|c|c|c|c|c|c|c|c|c|c|c|}
\hline & \multicolumn{2}{|c|}{ Deposit } & \multicolumn{2}{|l|}{$\mathrm{Fe}$} & \multicolumn{2}{|l|}{$\mathrm{Mn}$} & \multicolumn{2}{|l|}{$\mathrm{Al}$} & \multicolumn{2}{|l|}{$P$} \\
\hline & Std & $t$ & Std & $t$ & Std & $t$ & Std & $t$ & Std & $t$ \\
\hline & Coeff & & Coeff & & Coeff & & Coeff & & Coeff & \\
\hline Water concentration & & & 0.42 & $3.40^{\star \star}$ & 0.39 & 1.70 & -0.16 & 0.89 & 0.12 & 0.72 \\
\hline Algal biomass & 0.07 & $2.00^{*}$ & -0.09 & 1.13 & -0.20 & 1.37 & 0.52 & $2.54^{\star \star}$ & -0.03 & 0.26 \\
\hline NPD biomass & 0.68 & $2.90 * \star$ & 0.58 & $4.73^{\star \star \star}$ & 0.36 & 1.55 & 0.92 & 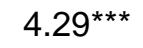 & 0.73 & $4.46^{\star \star}$ \\
\hline$R^{2}$ & 0.46 & & 0.88 & & 0.53 & & 0.47 & & 0.66 & \\
\hline
\end{tabular}

447

448

449

(b)

\begin{tabular}{|c|c|c|c|c|c|c|c|c|c|c|}
\hline & \multicolumn{2}{|c|}{ Deposit } & \multicolumn{2}{|l|}{$\mathrm{Fe}$} & \multicolumn{2}{|l|}{$\mathrm{Mn}$} & \multicolumn{2}{|l|}{$\mathrm{Al}$} & \multicolumn{2}{|l|}{$\mathrm{P}$} \\
\hline & Std & $t$ & Std & $t$ & Std & $t$ & Std & $t$ & Std & $t$ \\
\hline & Coeff & & Coeff & & Coeff & & Coeff & & Coeff & \\
\hline Water concentration & & & -0.01 & 0.29 & -0.11 & 1.30 & -0.03 & 0.70 & 0.05 & 1.63 \\
\hline DO & 0.01 & 0.38 & 0.00 & 0.02 & -0.01 & 0.07 & 0.03 & 0.69 & 0.01 & 0.13 \\
\hline $\mathrm{pH}$ & 0.01 & 1.73 & -0.02 & 0.50 & 0.17 & 1.82 & 0.02 & 0.33 & -0.14 & $3.15^{\star \star}$ \\
\hline Rain (28d) & 0.00 & 0.07 & -0.01 & 0.37 & -0.20 & 1.90 & 0.00 & 0.07 & 0.05 & 0.94 \\
\hline Rain (7d) & 0.04 & 1.39 & 0.03 & 0.87 & 0.21 & $2.19^{*}$ & 0.06 & 1.16 & -0.07 & 1.52 \\
\hline Algal biomass & 0.06 & $2.61^{*}$ & -0.03 & 1.13 & -0.23 & $2.71^{* *}$ & 0.06 & 1.25 & 0.01 & 0.03 \\
\hline NPD biomass & 0.47 & $23.75^{\star \star \star}$ & 0.62 & $23.43^{\star \star \star}$ & 0.55 & $8.69 * \star \star$ & 0.18 & $4.95^{\star \star \star}$ & 0.35 & $11.56^{\star \star \star}$ \\
\hline$R^{2}$ & 0.90 & & 0.93 & & 0.57 & & 0.30 & & 0.71 & \\
\hline
\end{tabular}


451 Table 5 Summary of linear and piecewise regression analyses (all values are $\log _{10} \mathrm{mg} \mathrm{cm}^{-2}, \mathrm{NPD}$

452 biomass as the independent variable, $n=75$ ) of the data shown in figure $3 . \Delta \mathrm{AICc}$ was used to

453 compare the fit of linear and piecewise models. The statistics of the best fitting models are shown:

454 breakpoint is the NPD biomass at which the line changes slope and b1 and b2 are the slopes below

455 and above the breakpoint. Significant slope values $(b=0)$ are shown in bold.

456

\begin{tabular}{lrrrrrrrr}
\hline Deposit variable & $\mathrm{a}$ & $\mathrm{b} 1$ & $\mathrm{~b} 2 \pm \mathrm{se}$ & breakpoint & $R^{2}$ & $\Delta \mathrm{AICc}$ & $t_{\mathrm{b} 2=1}$ & $P_{\mathrm{b} 2=1}$ \\
\hline $\mathrm{Fe}$ & -0.315 & $\mathbf{0 . 6 3 6}$ & $\mathbf{1 . 1 3 8} \pm 0.055$ & -0.117 & 0.94 & 30.84 & 2.51 & $<0.05$ \\
$\mathrm{Mn}$ & -1.092 & 0.022 & $\mathbf{1 . 2 2 5} \pm 0.213$ & 0.036 & 0.71 & 5.69 & 1.06 & \\
$\mathrm{Al}$ & -0.791 & -0.113 & $\mathbf{0 . 6 6 8} \pm 0.159$ & 0.325 & 0.87 & 13.19 & 2.09 & $<0.05$ \\
$\mathrm{P}$ & -2.011 & $\mathbf{0 . 3 6 3}$ & $\mathbf{1 . 5 8 3} \pm 0.251$ & 0.801 & 0.98 & 20.86 & 2.32 & $<0.05$ \\
\hline
\end{tabular}

457

458 
Running Head: INFLUENCES OF IN-STREAM FACTORS ON METAL DEPOSITS

\section{$459 \quad$ Figure captions}

460

461 Fig. 1 The percentage contribution of algae to organic matter in deposits across sites is bimodally 462 distributed.

463

464 Fig. 2 Seasonal changes in mean ( \pm 1 s.e.) algal (triangles) and NPD (circles) biomass ( $\left.\mathrm{mg} \mathrm{cm}^{-2}\right)$

465 across sites, between November 2007 and September 2008.

466

467 Fig. 3 Across the seasonally studied sites, Fe (circles), Mn (crosses), Al (diamonds) and P (triangles)

468 deposit densities change as NPD biomass increases. Lowess smoothed lines (tension 0.6) are fitted 469 to the data. 
Running Head: INFLUENCES OF IN-STREAM FACTORS ON METAL DEPOSITS

470

471

472

473

474

475

476

477

478

479

480

481

482

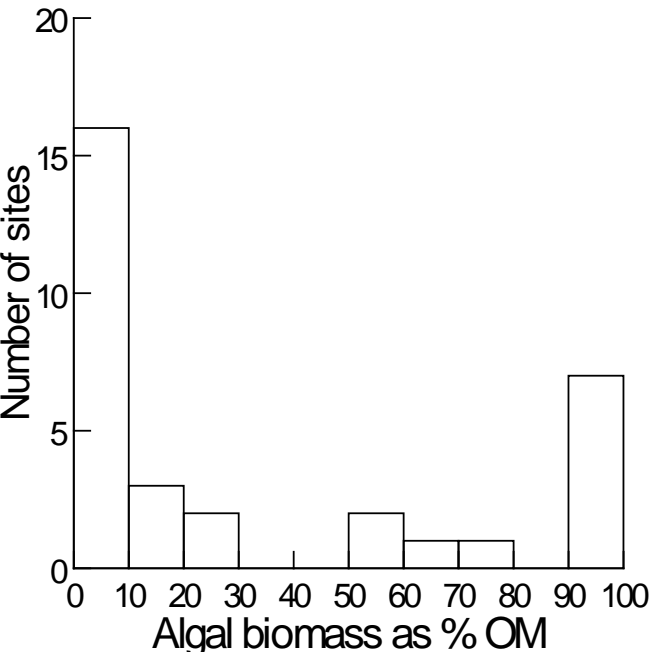

Fig. 1 
Running Head: INFLUENCES OF IN-STREAM FACTORS ON METAL DEPOSITS

483

484

485

486

487

488

489

490

491

492

493

494

495

496

497

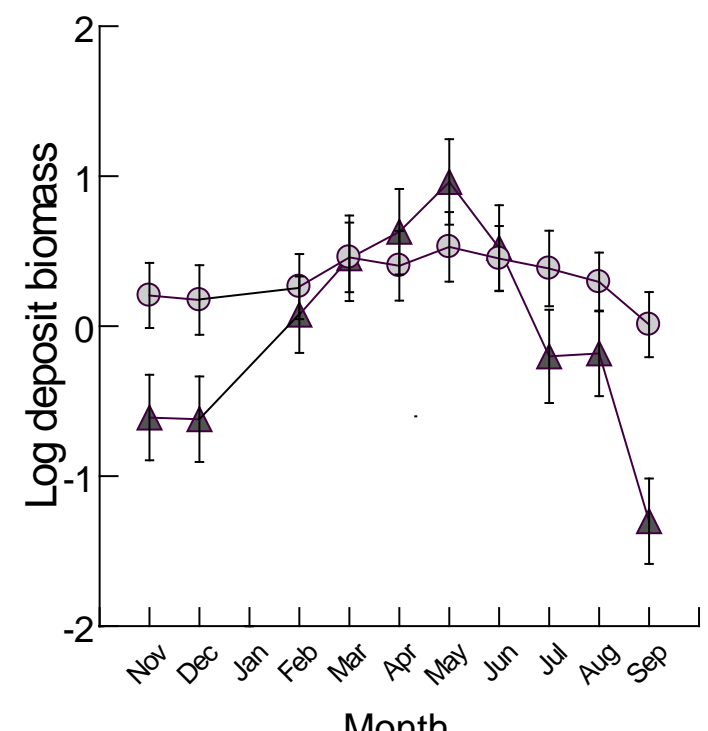

Month

Fig. 2 
Running Head: INFLUENCES OF IN-STREAM FACTORS ON METAL DEPOSITS

498

499

500

501

502

503

504

505

506

507

508

509

510

511

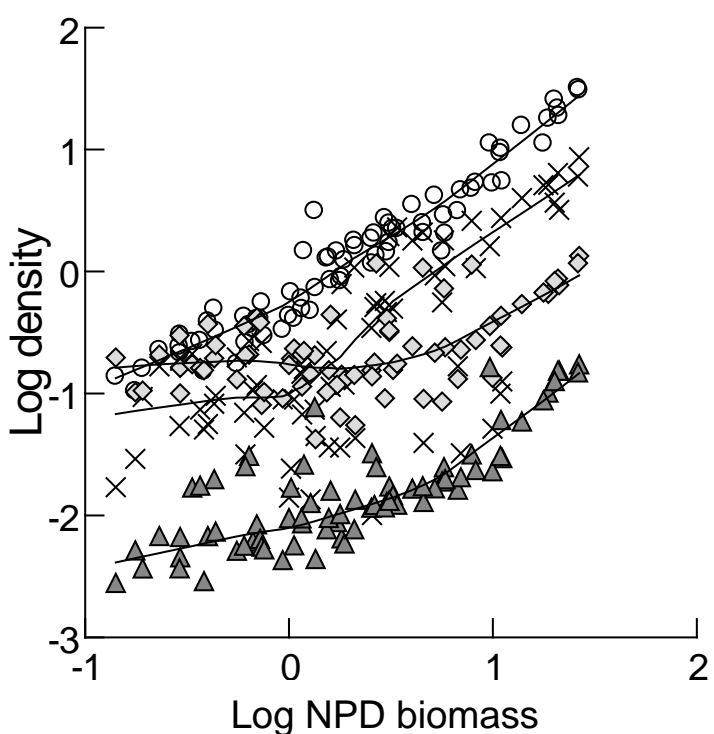

Fig. 3 